\title{
鋼板・コンクリート合成床版のスタッドに㗢く せん断力と押し抜きせん断耐力

\author{
SHEARING FORCE ON STUDS AND PUNCHING SHEAR LOAD \\ OF A STEEL PLATE AND CONCRETE COMPOSITE SLAB
}

\author{
園田恵一郎* ·堀川都志雄** ·鬼 頭 宏 明*** 一 木兽収一郎**** \\ By Keiichiro SONODA, Toshio HORIKAWA, Hiroaki KITOH and Shuichiro KISO
}

\begin{abstract}
A steel plate and concrete composite slab (so-called Robinson slab) is analyzed using a collocation method based on an elastic thick plate theory. A special attention is paid to the shearing force characteristics of studs in the slabs, and the effects of the spacing of stud, the thickness of steel plate and others on them are examined. Summarizing the analytical results obtained for various bridge deck models, a formula for estimating the maximum shearing force of studs is proposed.

Model slabs are tested under a static patch load. A good agreement between the analytical results and the test results is found.

Keywords: bridge deck, composite slab, stud, shearing force, fatigue, load carrying capacity
\end{abstract}

\section{1. 緒論}

従来の道路橋鉄筋コンクリート床版（以下 RC 床版 と略称する）に替わる新しい形式の合成床版としては, 今日, 鋼格子床版, サンドイッチ合成スラブ, 波形鋼型 枠埋設床版，プレキャスト鋼板コンクリート合成床版な ビの実用化がみられるが，最もオーソドックスなものは Robinson slabとして知られる鋼板・コンクリート合成 床版と思われる．この床版は，頭付きスタッドが溶植さ れた薄鋼板を埋め殺し型枠とし，これを現場打ちコンク リートと合成することを基本としており，1959年にフ ランスの tancarville 橋1)に最初に採用され, わが国では, 最近, 首都高速道路公団で適用例 ${ }^{2)}$ がみられる.

ところで,この種の合成床版を設計しようとする場合， 特に次の 2 つの点に留意しなければならない。第 1 は静 的耐荷力特性であり, 第 2 は疲労特性である. 一般的に いって, この種の合成床版では, 生コンクリートの重量

* 正会員 工博 大阪市立大学教授 工学部土木工学科 （元558 大阪市住吉区杉本 3-3-138）

** 正会員 工博 大阪工業大学助教授 工学部土木工学科 （５355 大阪市旭区大宮 5-16-1）

*** 正会員 工修 大阪市立大学助手 工学部土木工学科 （㣙58 大阪市住吉区杉本 3-3-138）

**** 正会員 工修 (株) 春本鉄工所設計部設計課 （テ551 大阪市大正区南恩加島 6-20-34）
や作業荷重を支える型枠として機能できる鋼板の断面積 は通常の RC 床版の鉄筋の断面積よりもかなり大きく なるので，十分な曲げ強度をもつことができる. しかし ながら，せん断力は主としてコンクリート断面で受け持 たねばならないので, 局所的な輪荷重の作用下での床版 の耐力はコンクリートのせん断強度かまたは鋼板の付着 せん断強度に支配されるものと思われる. 一方, 疲労の 問題は, 自動車荷重の反復を受ける道路橋床版では重要 である. 特に, スタッドの溶植部には応力集中が避けが たいのでこの種の床版の疲労強度の低下が眯念される.

本研究は鋼板・コンクリート合成床版のせん断強度と スタッド付き鋼板の疲労に着目している.この問題に深 く関連した既往の研究としては, 前田・梶川 ${ }^{3)}$ のスタッ ド付き薄鋼板の疲労実験があり, 彼らは実験結果を整理 して次のような疲労寿命 $\left(N_{f}\right)$ の評価式を提案している.

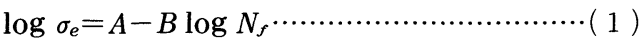

$$
\begin{aligned}
& \sigma_{e}=\sqrt{\left(\alpha \sigma_{0}^{2}+\beta \tau_{0}^{2}+\gamma \sigma_{0} \tau_{0}\right)}
\end{aligned}
$$

ここに, $A$ と $B$ はスタッドのない薄鋼板の $S-N$ 曲線 での係数であり,これらは同種の鋼材のクーポン試験か ら求められ， $\alpha, \beta$ と $\gamma$ は応力集中に関係した係数であ り，文献 3) では $\phi 19$ の頭付きスタッドと鋼板厚 10 $\mathrm{mm}$ の実験よりこれらの係数を与えている. また， $\sigma_{0}$ と $\tau_{0}$ はそれぞれ薄鋼板に作用する平均引張応力とス夕ッ 
ド基部に作用するせん断力である．式（1）は合成桁の フランジのスタッドを対象として提案されたものである が，類似の組合せ力を受ける鋼板・コンクリート合成床 版のスタッドに対しても式（1）と同じ形式の評価式が 適用できると考えられ， $\sigma_{0}$ は平板の曲げ引張応力とし て次式で容易に求められる。

$$
\sigma_{0}=M_{p} / Z
$$

ここに, $M_{p}$ は平板理論により求められる曲げモーメン

ト, $Z$ は合成断面としての断面係数である. それに反 して， $\tau_{0}$ の決定はかなり厄介な問題である．もし床版 のコンクリートと鋼板が全面で接着されたいわゆる完全 合成の場合は，付着せん断応力 $\tau_{0}$ は次式で求められる.

$$
\tau_{0}=G_{s} Q_{p} / I
$$

ここに， $Q_{p}$ は平板理論より求められるせん断力, $I$ は 合成断面のコンクリート換算断面 2 次モーメント， $G_{s}$ は合成断面の中立軸に関する鋼板のコンクリート換算断 面 1 次モーメントである. しかしながら，実用的な見地 からはスタッドの間隔はあまり小さくできなく, 完全合 成亡しての取扱い4) は十分之は思われない。たとえば, 前述の Tancarville 橋では, $\phi 16$ の頭付きスタッドの平 均間隔は 15 16 mm で, 首都高速道路公団の橋梁床版 では $\phi 13 \mathrm{~mm}$ のスタッドの最小間隔は $10 \mathrm{~cm}$ である.

本研究の主たる目的は, 種々の間隔のスタッドをもつ 鋼板・コンクリート合成床版の疲労設計のための輸荷重 下でのスタッドに働く最大せん断力の算定式を得るこ と，ならびにこの床版のせん断破壊のメカニズムを明ら かにし終局耐力の評価法を見出すことである。なお，ス タッドに働くせん断力に対する数值解析法とモデル床版 の弾性実験についてはすでに前論文 ${ }^{5)}$ で発表している が, 本論文は, 多種の諸元をもつ床版の解析結果と破壊 実験結果を含めてまとめたものである.

\section{2. 理 論}

\section{（1）厚板理論に基づく選点法}

薄鋼板とコンクリート板は, スタッドのみで連結して いるとする．すなわち，鋼板とコンクリートの間の自然 付着力は長期の繰り返し荷重の作用下では保証できず, 設計上は期待できないものと考える.一般にスタッドと 鋼板の溶接部にはきわめて高い応力集中が発生するが, 応力集中の問題は式 $(2$ ) の実験式の中で考慮されてい るとし，ここでは，スタッド溶着部に働く力（以下， ス タッド力と略称する）のみに着目する. 理論解析では, スタッド力，すなわち鋼板とコンクリート板の間の伝達 カはスタッドの溶着部内に一様に分布すると仮定し,こ の力をフーリエ級数で展開し選点法 (Collocation Method）によってスタッド溶着部の中心で変形適合さ せる. スタッドの断面はコンクリート厚や床版のスパン

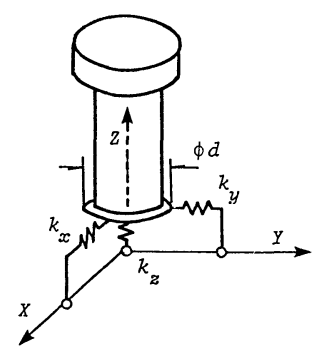

図一1 スタッドカとばね係数

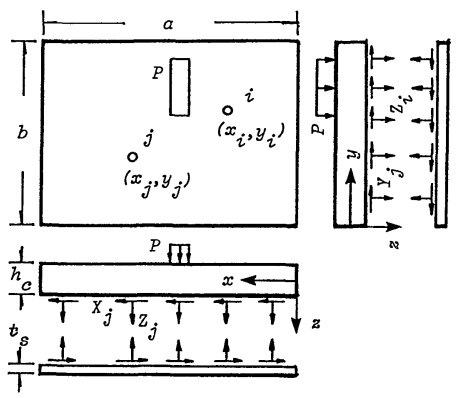

図一2 作用力と座標

に比して非常に小さいので, 選点法に用いる素解は局所 的な変形性状が考慮できる三次元弾性論に基づく厚板理 論6)による.すなわち，スタッド力は，図一1に示すよ

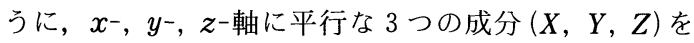
もち，これらの成分は 1 辺が $0.886 d （ d$ はスタッド溶 着部の直径) の正方形の上に一様に分布するとし，単位 力 $(X=1, Y=1, Z=1)$ による厚板の変位解を素解 として用い，各成分を以下の手順により決定する.

三次元弾性論におけるガレルキンベクトル (Galerkin vector) の $z$-軸成分 $W$ とブーシネスク (Bousinesq) 関数 $\theta$ は次のように与えられる.

$\Delta \Delta W=0, \quad \Delta \theta=0$ $(5 \cdot a, b)$

ここに, $\Delta=\partial^{2} / \partial x^{2}+\partial^{2} / \partial y^{2}+\partial^{2} / \partial z^{2}$

図一2に示すような座標系 $(x, y, z)$ を用い, 各座標軸 に沿った変位成分 $(u, v, w)$ は

$$
\left.\begin{array}{l}
2 \mu u=-\partial^{2} W / \partial x \partial z+\partial \theta / \partial y \\
2 \mu v=-\partial^{2} W / \partial y \partial z-\partial \theta / \partial x \\
2 \mu w=2(1-\nu) \Delta W-\partial^{2} W / \partial z^{2}
\end{array}\right\} \cdots \cdots \cdots(6 \cdot \mathrm{a}, \mathrm{b}, \mathrm{c})
$$$$
\text { ここに, } \mu=E / 2(1+\nu), \nu: \text { ポアソン比, } E: \text { ヤング率 }
$$

周辺が単純支持された長方形板に対しては, 式 ( 5 )

の一般解は次のような三角級数で与えられる.

$$
\begin{aligned}
& W=\sum_{m} \sum_{n}\left\{C_{1} \operatorname{sh} \gamma z+C_{2} \operatorname{ch} \gamma z\right. \\
& \left.\quad+\gamma z\left(C_{3} \operatorname{sh} \gamma z+C_{4} \operatorname{ch} \gamma z\right)\right\} \sin \alpha x \sin \beta y \\
& \theta=\sum_{m} \sum_{n}\left(C_{5} \operatorname{sh} \gamma z+C_{6} \operatorname{ch} \gamma z\right) \cos \alpha x \cos \beta y
\end{aligned}
$$


ここに, $\alpha=m \pi / a, \beta=n \pi / b, m, n$ は級数の項数, $\operatorname{sh} \gamma z=\sinh \gamma z, \operatorname{ch} \gamma z=\cosh \gamma z, C_{1} \sim C_{6}$ は積分定 数で板の上, 下面の応力条件より決定できる.

式（7）を式（6）に代入すれば，各変位成分は

$$
\begin{aligned}
2 \mu u= & -\sum_{m} \sum_{n}\left\{C_{1} \operatorname{ch} \gamma z+C_{2} \operatorname{sh} \gamma z\right. \\
& +C_{3}(\gamma z \operatorname{ch} \gamma z+\operatorname{sh} \gamma z) \\
& +C_{4}(\gamma z \operatorname{sh} \gamma z+\operatorname{ch} \gamma z)+\beta / \alpha \gamma\left(C_{5} \operatorname{sh} \gamma z\right. \\
& \left.\left.+C_{6} \operatorname{ch} \gamma z\right)\right\} \alpha \gamma \cos \alpha x \sin \beta y \\
2 \mu v= & -\sum_{m} \sum_{n}\left\{C_{1} \operatorname{ch} \gamma z+C_{2} \operatorname{sh} \gamma z\right. \\
& +C_{3}(\gamma z \operatorname{ch} \gamma z+\operatorname{sh} \gamma z) \\
& +C_{4}(\gamma z \operatorname{sh} \gamma z+\operatorname{ch} \gamma z)-\alpha / \beta \gamma\left(C_{5} \operatorname{sh} \gamma z\right. \\
& \left.\left.+C_{6} \operatorname{ch} \gamma z\right)\right\} \beta \gamma \sin \alpha x \cos \beta y \\
2 \mu w= & -\sum_{m} \sum_{n}\left[C_{1} \operatorname{sh} \gamma z+C_{2} \operatorname{ch} \gamma z\right. \\
& +C_{3}\{\gamma z \operatorname{sh} \gamma z-2(1-2 \nu) \operatorname{ch} \gamma z\} \\
& +C_{4}\{\gamma z \operatorname{ch} \gamma z-2(1-2 \nu) \operatorname{sh} \gamma z\} \\
& \cdot \gamma^{2} \sin \alpha x \sin \beta y
\end{aligned}
$$

さて, 本研究で対象とする合成床版はコンクリート板 と鋼板の 2 層より成っており, 上層の上面は自動車の輪 荷重を受け，上層の下面と下層の上面はスタッド力を受 けている。いま, 図一2に示すように, 座標 $\left(x_{i}, y_{i}\right)$ の スタッド力を $\left(X_{i}, Y_{i}, Z_{i}\right)$ とし, これらと輪荷重をとも にフーリエ級数で展開し, 係数間の比較によって式 $(8)$ の中の積分定数を決定する.

次に，鋼板に設けられた全スタッド数を $N$ とすれば, 任意点 $\left(x_{i}, y_{i}\right)$ での変位成分は次式で表わされる.

$$
\begin{aligned}
& u_{i}^{c, s}=u_{0 i}^{c, s}+\sum_{j=1}^{N}\left(u_{1 j}^{c, s} X_{j}+u_{2 j}^{c, s} Y_{j}+u_{3 j}^{c, s} Z_{j}\right) \\
& v_{i}^{c, s}=v_{0 i}^{c, s}+\sum_{j=1}^{N}\left(v_{1 j}^{c, s} X_{j}+v_{2 j}^{c, s} Y_{j}+v_{3 j}^{c, s} Z_{j}\right) \\
& w_{i}^{c, s}=w_{0 i}^{c, s}+\sum_{j=1}^{N}\left(w_{1 j}^{c, s} X_{j}+w_{2 j}^{c, s} Y_{j}+w_{3 j}^{c, s} Z_{j}\right)
\end{aligned}
$$

ここに，上添字の $c$ はコンクリート板， $s$ は鋼板を参 照し， $u_{0 i}^{c, s} ， v_{0 i}^{c, s} ， w_{0 i}^{c, s}$ は輪荷重に対して式（8）加ら求 められる変位成分, $u_{l j}^{c, s}, v_{l j}^{c, s}, w_{l j}^{c, s}$ は, $l=1, l=2, l$ $=3$ についてそれぞれ $X_{j}=1, Y_{j}=1, Z_{j}=1$ に対して式

（８）加求められる変位成分である.

さて，一般にスタッドは剛でなくたわみ性がある。た とえば，Fisher ら”が押し抜き試験から求めた実験式で は，スタッドの剛性（ずれ係数）は次式で表わされる.

$$
k=\frac{Q}{\delta}=\frac{80 Q_{u}}{1+80 \delta}
$$

ここに，Q はスタッドの作用せん断力， $Q_{u}$ はスタッド の終局せん断耐力, $\delta$ はずれで単位はインチである. と ころで, スタッド力は 3 成分をもつので, 解析では図一
1 に示すように各成分に対するずれ係数をばね係数とし て表わし，次の関係をもたせる.

$$
X_{i}=k_{x} \delta_{x i}, \quad Y_{i}=k_{y} \delta_{y i}, \quad Z_{i}=k_{z} \delta_{z i} \quad(i=1,2, \cdots N)
$$

$$
(11 \cdot a, b, c)
$$

ここに, $k_{x}, k_{y}, k_{z}$ は式 (10) に対応しており， $\delta_{x i}$, $\delta_{y i}, \delta_{z i}$ はコンクリート板と鋼板の相対変位の座標方向 成分であり, 式 $(9)$ を用い

$$
\delta_{x i}=u_{i}^{s}-u_{i}^{c}, \quad \delta_{y i}=v_{i}^{s}-v_{i}^{c}, \quad \delta_{z i}=w_{i}^{s}-w_{i}^{c}
$$

$$
(12 \cdot a, b, c)
$$

で与えられる。したがって，式（9）と（12）を式 (11) に代入すれば，スタッド力 $\left(X_{i}, Y_{i}, Z_{i}\right)$ を決定するため の次の連立 1 次方程式を得る.

$$
\left(\boldsymbol{F}-\boldsymbol{K}^{-1}\right) \boldsymbol{Q}=\boldsymbol{u}_{0}
$$

\begin{tabular}{|c|c|c|c|}
\hline 項数 & \multicolumn{3}{|c|}{ X=1による着目点の変位 } \\
\hline$m(=n)$ & $u\left(x 10^{-3}\right)$ & $\mathrm{V}\left(\times 10^{-5}\right)$ & $w\left(\times 10^{-3}\right)$ \\
\hline 50 & -7.730 & -5.307 & -9.302 \\
\hline 100 & -9.041 & -5.307 & -9.278 \\
\hline 150 & -9.542 & -5.318 & $-9: 282$ \\
\hline 200 & -9.694 & -5.308 & -9.282 \\
\hline 250 & -9.720 & -5.301 & " \\
\hline 300 & -9.742 & -5.308 & "I \\
\hline 350 & -9.763 & -5.312 & " \\
\hline 400 & -9.778 & -5.308 & " \\
\hline 450 & -9.808 & -5.305 & "I \\
\hline 500 & -9.858 & -5.308 & " \\
\hline 項数 & \multicolumn{3}{|c|}{ Z=1による着目点の変位 } \\
\hline $\mathrm{m}(=\mathrm{n})$ & $u\left(x 10^{-3}\right)$ & $\mathrm{v}\left(x 10^{-2}\right)$ & $\mathrm{w}$ \\
\hline 50 & -9.302 & -4.849 & 4.742 \\
\hline 100 & -9.278 & -4.849 & 4.745 \\
\hline 150 & -9.282 & -4.849 & 4.745 \\
\hline 200 & -9.282 & $" \prime$ & "I \\
\hline 250 & "I & "I & "I \\
\hline 300 & "I & "I & "I \\
\hline 350 & "I & "I & " \\
\hline 400 & " & "I & "I \\
\hline 450 & " & "I & "I \\
\hline 500 & II & 11 & II \\
\hline
\end{tabular}

ここに，Qははスタッド力を表わすべクトル， $K$ はばね 係数から成る対角行列, $\boldsymbol{u}_{0}$ は輪荷重による変位ベクト ル，F は単位のスタッドカによる相対変位成分を表わ す行列（すなわち柔性行列）である. 式 (13) の解より 各スタッド力の成分が決定でき, 式 $(2)$ の $\tau_{0}$ を与え るスタッドのせん断応力は次式で求められる.

$$
\tau_{0 i}=\sqrt{\left(X_{i}^{2}+Y_{i}^{2}\right)} / a_{s}
$$

ここに， $a_{s}$ はスタッドの断面積である.

\section{（2） 級数解の収束性と数値計算法}

選点法の素解には式 ( 8 ) の級数解を用いている. と ころで, スタッドの径に比して床版のスパンは非常に大 きくなるので, スタッドカをフーリエ級数で精度良く展 開するには非常に多くの項数を必要とし, 級数の収束性 を事前に十分に調べておかねばならない，そこで，収束 性が最も厳しくなると予想される単位のスタッドカによ る鋼板の変位に関する級数の収束性を調べた，検討した 鋼板は長さ $100 \mathrm{~cm}$, 幅 $200 \mathrm{~cm}$, 厚さ $10 \mathrm{~mm}$ で, 周辺で

\section{表一1 級数解の収束性}


単純支持されており，スタッド力は鋼板の上面の正方形 $(20 \mathrm{~mm} \times 20 \mathrm{~mm})$ に一様分布させている.

表一1 はスタッド力の単位水平成分 $X=1 \mathrm{tf}$ および単 位鉛直成分 $Z=1 \mathrm{tf}$ によるスタッド溶着部の中心点での 変位成分の収束状況を示したものである. 水平力 $(X=$ 1) による水平変位成分 $(u)$ の収束性が最も悪く, 項数 を 500 にとってもまだわずかではあるが脈動している. 実際の橋梁床版でのスタッドの径とスパンの比はこのモ デルよりもっと大きくなり，完全な収束值を求めること が困難になるので， $u, v$ については級数和の脈動幅が $1 \%$ 以内になったときの平均值を収束值とみなした。 着目スタッドより離れたスタッドの位置での変位の収束 性は非常によいので，このような処置による結果は工学 的には十分な精度をもっていると思われる。

一方, 選点法に必要な素解の種類は, 式 (9) で示し たように，18 個であり，それぞれより $N$ (スタッドの 総数) 個の数値デー夕を求めて式 (13) の連立 1 次方程 式の係数を決定する. しかしながら，局所的な輪荷重に よるせん断力は荷重面の近傍に集中すること，ならびに スタッドカによる変位の大きさを着目点から離れるにつ れて急速に減少することを考慮すれば，輪荷重の作用面 から短スパン直角方向に遠く離れたスタッドの影響は無 視でき，数値計算の効率化が図れる.そこで，いくつか の試算により, 短スパン長程度の幅の中にあるスタッド のみを考慮し，それ以上離れたスタッドを無視してもス タッド力の最大值には影響を与えないことがわかったの で，次節に示す実橋床版の解析モデルに対してはこのよ うな数值計算の効率化を図った.

\section{3. 道路橋床版の後輪荷重下でのスタッドに働 くせん断力}

\section{(1) 解析モデル}

橋梁床版は主析によって支えられた連続版であるが， スパンに比して厚みの小さな平板が輪荷重のような局所 的な荷重を受ける場合のせん断力分布は荷重特性に支配 され，板の支持条件の影響は少ないと考えられる．した がって, 解析の便宜上, 隣接縦桁に挟まれた 1 パネルの 床版を取り出し，図一3に示すようなアスペクト比が十 分に大きく帯状版とみなせる周辺単純支持長方形版を解 析モデルに選ぶ。作用荷重はわが国の道路橋示方書で規 定された $T$ 荷重の後輪刷1)，すなわち $50 \mathrm{~cm} \times 20 \mathrm{~cm}$ の 長方形上の等分布荷重（大きさは $P=1 \mathrm{tf}$ を基準に用い た）である．荷重位置は図一3の 2 か所であり，Case I は端部載荷で荷重面の縁が長辺に平行な支持線に最も

注 1）平板のせん断力は局所荷重の近傍に集中し，それから 離れるにつれて急速に減衰するので, 着目する後輪以外 の他の輪の影響は小さいと思われる。
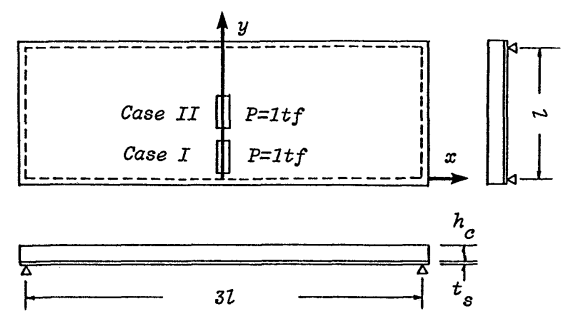

図一3 解析モデル

表一2 解析モデルの種類と諸元

\begin{tabular}{|c|c|c|}
\hline 項目 & 钎号 & 適用値 \\
\hline 床版支間 & $l$ & $2 m, 3 m$ \\
\hline コンクリート厚 & h c & $10 \mathrm{~cm}, 15 \mathrm{~cm}, 20 \mathrm{~cm}$ \\
\hline 鋗板厚 & $t s$ & $6 \mathrm{~mm}, 10 \mathrm{~mm}$ \\
\hline スタッド間隔 & $\lambda \times$ & $15 \mathrm{~cm}, 20 \mathrm{~cm}, 30 \mathrm{~cm}, 40 \mathrm{~cm}$ \\
\hline & $\lambda y$ & $10 \mathrm{~cm}, 15 \mathrm{~cm}, 20 \mathrm{~cm}, 30 \mathrm{~cm}$ \\
\hline 弾性係数比 & n & 7,15 \\
\hline 载荷位圈 & Case & $I$ :端部载荷, II：中央载荷 \\
\hline
\end{tabular}

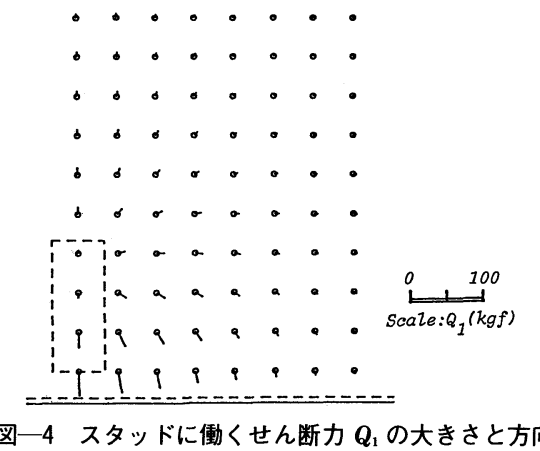

$\left(\lambda_{x}=\lambda_{y}=15 \mathrm{~cm}\right.$, Case I )

近いスタッドの列の上にあり，せん断力が支配する場合 である. Case II は中央載荷で荷重面の中心が床版の中 心にあり，曲げの影響を大きく受ける場合である．使用 スタッドの直径は $16 \mathrm{~mm}$ とし, 解析上は $14 \mathrm{~mm} \times 14$ $\mathrm{mm}$ の正方形として取り扱う. 解析モデルの種類と諸元 を表一2に示す．また，鋼の弾性係数を $E_{s}$ ，コンクリー 卜の弾性係数を $E_{c}$ とし, その比 $n=E_{s} / E_{c}$ は 7 または 15 とした.

\section{（2）一般的特性}

ここではスパン $(l=2 \mathrm{~m})$ ，コンクリート厚 $\left(h_{c}=15\right.$ $\mathrm{cm})$ ，鋼板厚 $\left(t_{s}=6 \mathrm{~mm}\right), n=7$ の床版を基準に選び, この床版の一般的特性を調べる，最初にスタッドに働く せん断力の分布特性を図一 4 に示す．図は Case I の解 析結果で, $x-y$ 座標の第 1 象限の一部であるが, スタッ ドに働く最大せん断力は載荷面の縁で発生し，その方向 は短スパンに平行であり，載荷面から遠ざかるにつれて せん断力は小さくなりその方向は載荷面の中心に向か う.

次に，スタッド剛性 $\left(k_{x}=k_{y}=k, k_{z}=\infty\right)$ がせん断 
表一3スタッドの最大せん断カについての他の理論との比較

\begin{tabular}{|c|c|c|c|c|c|c|c|c|}
\hline \multirow{2}{*}{$\begin{array}{l}\text { 载 倚 } \\
\text { 位監 }\end{array}$} & \multirow{2}{*}{$\lambda \times$} & \multirow{2}{*}{$\lambda y$} & \multirow{2}{*}{ ECCS } & \multirow{2}{*}{$\begin{array}{c}\text { 完全合成 } \\
\text { 理踚 }\end{array}$} & \multicolumn{2}{|c|}{ 本 } & \multicolumn{2}{|c|}{ 郭 $\quad(n=10)$} \\
\hline & & & & & $k=\infty$ & $=10 \times 10^{5}$ & $=5 \times 10^{5}$ & $=1 \times 10^{5}$ \\
\hline Case I & 20 & 30 & 36 & 445 & 96.9 & 85.9 & 77.3 & 44.4 \\
\hline " & 30 & 30 & 551 & 667 & 114.0 & 9.8 & 89.0 & 48.8 \\
\hline Case II & 20 & 30 & 176 & 270 & 70.2 & 64.5 & 59.7 & 40.6 \\
\hline II & 30 & 30 & 264 & 404 & 88.7 & 81.6 & 75.5 & 47.3 \\
\hline
\end{tabular}

(注)せん断力は $\mathrm{P}=1 \mathrm{tfk}$ 対する值 $(\mathrm{kgf}), \lambda x, \lambda$, の単位は $\mathrm{cm}, \mathrm{k}$ 單位は $\mathrm{kgf} / \mathrm{cm}$.

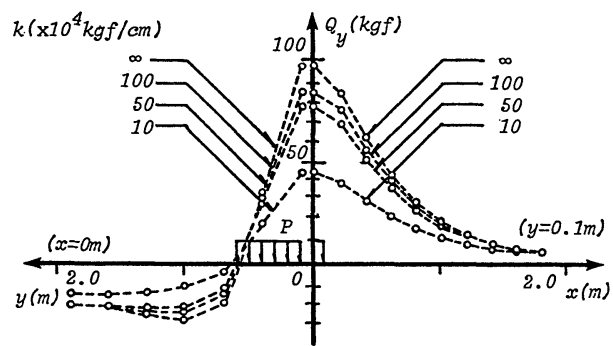

図一5 スタッドのせん断力分布に対する剛性の影響 $\left(\lambda_{x}=20 \mathrm{~cm}, \lambda_{y}=30 \mathrm{~cm}\right.$, Case I )
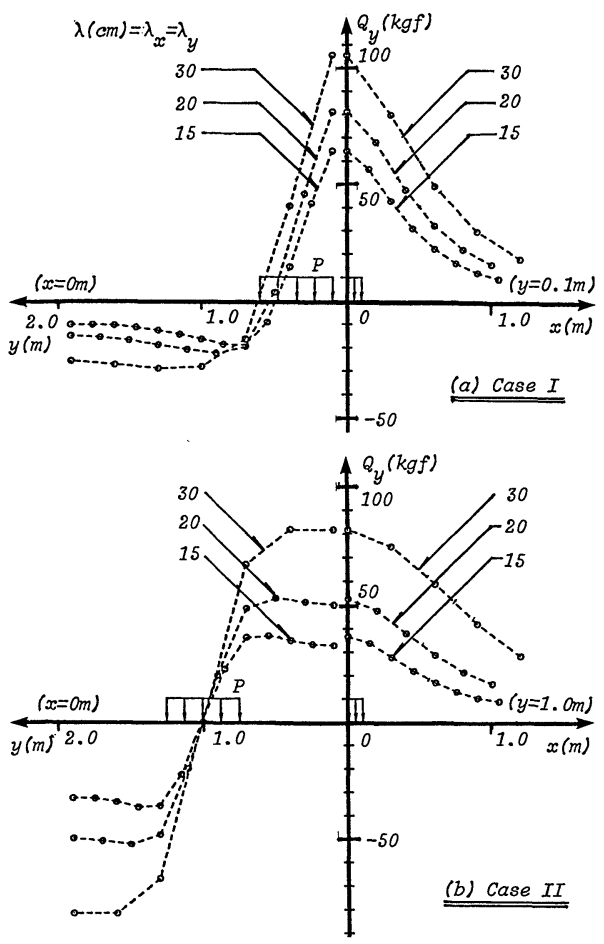

図一 6 スタッド間隔とせん断力分布 $(n=7)$

力分布に与える影響を調べたもの（ただし， $n=10 ）$ が 図一5である. $k$ が小さくなるにつれて最大せん断力の 值は減少するが， $k$ が $50 \times 10^{4} \mathrm{kgf} / \mathrm{cm}$ より大きくなれ ばスタッドの剛性の影響は鈍ることがわかる．表一3に は ECCS の設計基準8 による值および完全合成理論値 （文献 4）の積層厚板理論による付着せん断応力をス

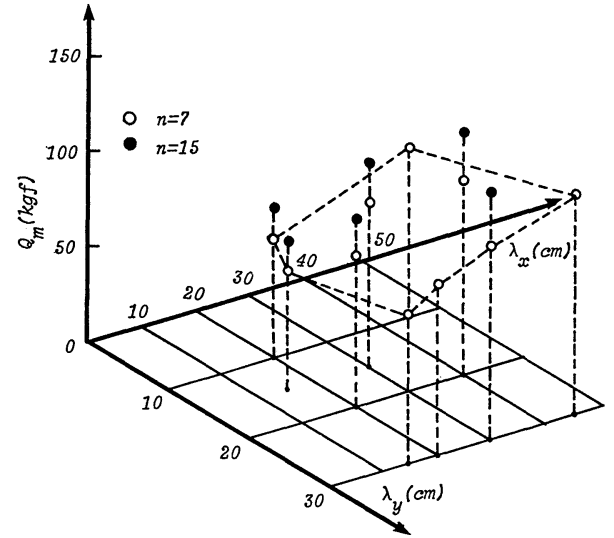

図一7 スタッド間隔と最大せん断カの関係

タッド間隔で積分したもの) と本解析結果との比較を示 している．スタッドの剛性を無限大としても本解析值は 他よりもかなり小さいことがわかるであろう.すなわち， 十分に剛なずれ止めであっても間隔が $20 〜 30 \mathrm{~cm}$ 程度 では床版は完全合成にはなり得ないといえる．この原因 については次節の実験結果との比較で検討する.

\section{（3） スタッドのせん断力特性}

スタッド間隔がスタッドに働く最大せん断力にどのよ うに影響するかを調べるために，スパン： $l=2.0 \mathrm{~m}$ ， コンクリート厚 : $h_{c}=15 \mathrm{~cm}$, 鋼板厚 : $t_{s}=6 \mathrm{~mm}$, スタッ ド剛性： $k\left(=k_{x}=k_{y}=k_{z}\right)=\infty$ のモデルに対して, ス タッド間隔 $\left(\lambda_{x}, \lambda_{y}\right)$ を種々変化させた解析を行った. $n$ $=7$ の場合の結果を図一 6 に示す．スタッド間隔が大き くなるにつれてせん断力の值は大きくなるが，その分布 形は変わらないことがわかる．また，端部載荷では最大 せん断力は荷重面の縁で起こるが，中央載荷ではスタッ ド間隔が大きくなると最大せん断力の位置は荷重面の縁 より支持辺側に移行することがわかる．さらに，最大せ ん断力に着目して解析結果を整理したものが図一7であ る. 最大せん断力はスタッドの間隔が大きくなるにつれ て増加するが増加率は比較的小さく，これは前述の完全 合成理論から得られる傾向とは大きく異なっている. ま た，コンクリートに対する鋼板の弾性係数比 $n$ が大き くなると最大せん断力の值が大きくなることもわかる.

次に，スタッド間隔を固定 $\left(\lambda_{x}=\lambda_{y}=15 \mathrm{~cm}\right) し て$, コンクリート厚, 鋼板厚がスタッドのせん断力分布によ゙ 
のように影響を与えるかを調べたものが図一8であり， 得られた結果を最大せん断力に着目して整理したものが 図一9である. 全般的な傾向としては鋼板厚が小さくコ ンクリート厚が大きくなるほ亡゙スタッドのせん断力は大 きくなるといえる．このことより，スタッドのせん断力 は, その值は別とすれば, 緒論で述べた完全合成理論に よる付着せん断応力である式（4）の中の $G_{s} / I$ に関係 することが示唆できる.

最後にスパンの影響を調べるために $l=3.0 \mathrm{~m}, h_{c}=$

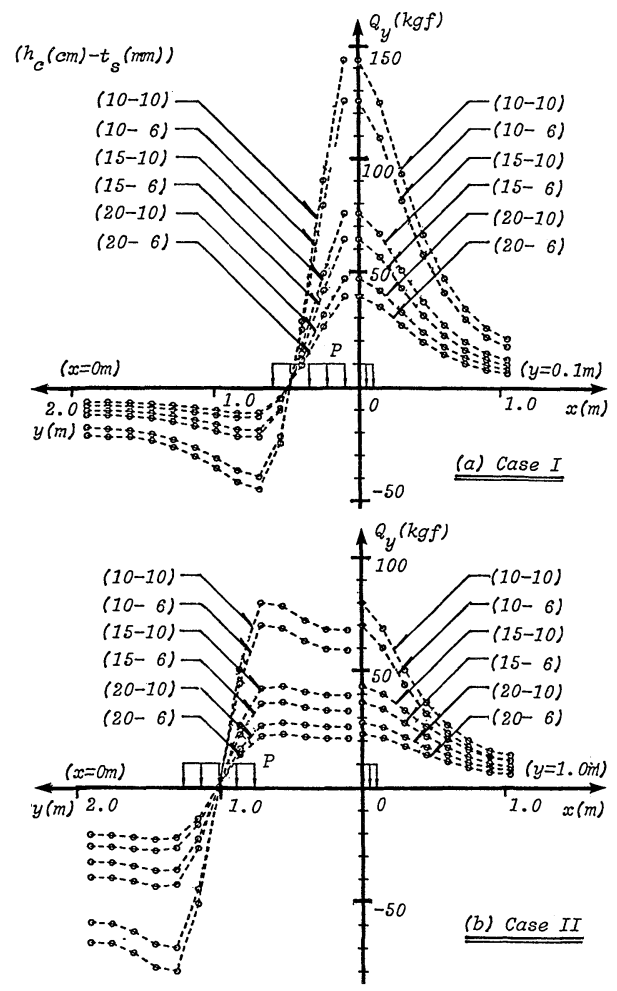

図一8 コンクリート厚，鋼板厚とせん断力分布 $(n=7)$

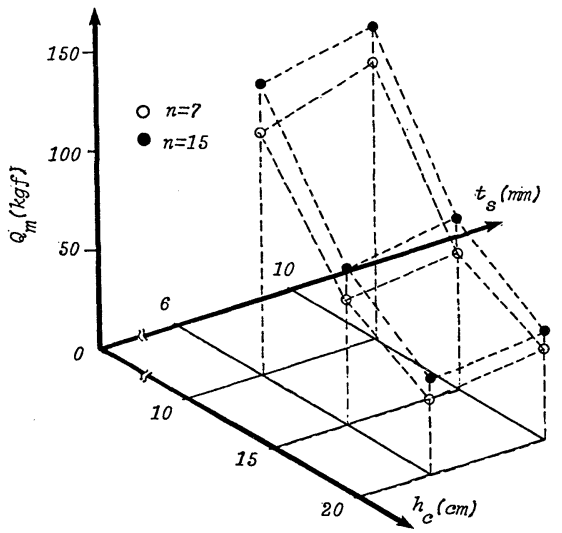

図一9 コンクリート厚，鋼板厚と最大せん断力の関係
$15 \mathrm{~cm}, t_{s}=6 \mathrm{~mm}, n=7$ のモデルの解析を行った. 結 果を表一 4 に示す. 表には, $l=2.0 \mathrm{~m}$ のモデルとの比 較も示すが，両者の差は高々 $10 \%$ 程度である.

\section{（4）最大せん断力の予測式}

$l=2.0 \mathrm{~m}, h_{c}=15 \mathrm{~cm}, t_{s}=6 \mathrm{~mm}$ の床版を基準に採り， 種々のスタッド間隔（ただし $k=\infty ）$ に対する最大せん 断力の解析結果を, 最小二乗法により整理すれば $P=$ $1 \mathrm{tf}$ 当たりの最大せん断力は以下のようになる.

$$
\begin{aligned}
\bar{Q}_{m}= & \alpha_{n}\left(-12.48+3.210 \lambda_{x}+3.081 \lambda_{y}-0.03536 \lambda_{x}^{2}\right. \\
& \left.+0.004436 \lambda_{x} \lambda_{y}-0.04846 \lambda_{y}^{2}\right) \\
\alpha_{n}= & 0.79+0.03 n
\end{aligned}
$$

$(15 \cdot a, b)$

ここに， $\bar{Q}_{m}$ の単位は $\mathrm{kgf}, \lambda_{x}, \lambda_{y}$ の単位は $\mathrm{cm}$ である. この近似式を用いれば, 解析值を $1.0 \%$ 以内の高精度 で予測することができる．次にコンクリート厚と鋼板厚 の影響は，すでに（3）で指摘したように，次の因子を 導入することによって考慮する.

$\gamma=G_{s} / I$

ここに， $G_{s}, I$ は式 $(4)$ で用いたものと同じである（た だし $G_{s}, I$ の算定において $n=7$ は全断面有効, $n=15$ はひびわれ断面を想定). $l=2.0 \mathrm{~m}, h_{c}=15 \mathrm{~cm}, t_{s}=6$ $\mathrm{mm}$ の基準床版の $\gamma$ を基準値 $\gamma_{0}$ とし，式（15）の值に $\gamma / \gamma_{0}$ をかけて補正すれば，次式を得る。

$Q_{m}=\left(\gamma / \gamma_{0}\right) \bar{Q}_{m}$

式 (17) による予測值と解析値との比較を表一5に示す. これより $+20 \%,-8 \%$ 以内の精度の予測值が得られ ることがわかる.また，（３）で述べたようにスパン $(l)$ の影響は実用上の範囲 $(2 \mathrm{~m} \leqq l \leqq 3 \mathrm{~m})$ では大きくなく 上記の精度の中に吸収されてしまうものと考えられるの で, 式 (17) によるスタッドの最大せん断力の予測式は,

表一4 スパンの相違による最大せん断力 $Q_{m}$ の変化

\begin{tabular}{cc|r|r|r|r}
\hline \multirow{2}{*}{$\begin{array}{c}\lambda \times, \\
\lambda_{y}\end{array}$} & \multicolumn{2}{|c|}{ Case I } & \multicolumn{2}{c}{ Case II } \\
\cline { 2 - 6 }$(\mathrm{cm})$ & $l=2 \mathrm{~cm}$ & $l=3 \mathrm{~m}$ & $l=2 \mathrm{~m}$ & $l=3 \mathrm{~m}$ \\
\hline 15 & 15 & 64.3 & 69.2 & 36.0 & 33.8 \\
20 & 20 & 81.2 & 82.9 & 53.0 & 48.4 \\
30 & 30 & 105.7 & 116.2 & 81.0 & 77.2 \\
\hline
\end{tabular}

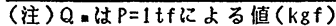

表一5 スタッドの最大せん断カの予測值と解析値の比較

\begin{tabular}{rrrrrrr}
\hline $\mathrm{h} c$ & $\mathrm{ts}$ & $\mathrm{n}$ & $\mathrm{r} / \mathrm{r}_{0}$ & $\mathrm{Qm}$ & $\mathrm{Qm}^{\prime}$ & $\mathrm{Q}_{\mathrm{m}} / \mathrm{Qm}^{\prime}$ \\
\hline \multirow{2}{*}{10} & \multirow{2}{*}{6} & 7 & 1.916 & 123.2 & 125.6 & 0.981 \\
& & 15 & 1.722 & 138.3 & 150.9 & 0.917 \\
\hline \multirow{2}{*}{10} & \multirow{2}{*}{10} & 7 & 2.370 & 152.4 & 143.5 & 1.062 \\
& & 15 & 2.049 & 164.5 & 161.4 & 1.018 \\
\hline \multirow{2}{*}{15} & \multirow{2}{*}{6} & 7 & 1.000 & 64.3 & 64.3 & 1.000 \\
& & 15 & 1.000 & 80.3 & 80.3 & 1.000 \\
\hline \multirow{2}{*}{15} & \multirow{2}{*}{10} & 7 & 1.336 & 85.9 & 75.7 & 1.135 \\
& & 15 & 1.188 & 95.4 & 88.0 & 1.084 \\
\multirow{2}{*}{20} & \multirow{2}{*}{6} & 7 & 0.673 & 43.3 & 39.3 & 1.102 \\
& & 15 & 0.674 & 54.1 & 50.3 & 1.076 \\
\multirow{2}{*}{20} & \multirow{2}{*}{10} & 7 & 0.881 & 56.6 & 47.0 & 1.204 \\
& & 15 & 0.810 & 65.0 & 55.9 & 1.163
\end{tabular}

(注) $\mathrm{Q} m, \mathrm{Qm}$ 'は，それそれ式(17)による予测值，解析值

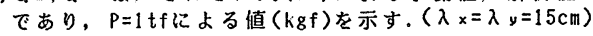


$10 \mathrm{~cm} \leqq h_{c} \leqq 20 \mathrm{~cm}, 6 \mathrm{~mm} \leqq t_{s} \leqq 10 \mathrm{~mm}, 10 \mathrm{~cm} \leqq\left(\lambda_{x}, \lambda_{y}\right)$ $\leqq 45 \mathrm{~cm}$ の範用内では実用的な精度をもつと思われる.

\section{4. モデル床版の実験}

\section{（1）実験の方法}

実験床版は短辺 $1.1 \mathrm{~m}$, 長辺 $2.1 \mathrm{~m}$, 鋼板厚 $9 \mathrm{~mm}$, コンクリート厚 $11 \mathrm{~cm}$ で, スタッドの配置間隔は短辺 方向には $15 \mathrm{~cm}$ で長辺方向は $7.5 \mathrm{~cm}, 10 \mathrm{~cm}, 15 \mathrm{~cm}$ お よび $20 \mathrm{~cm}$ のものと端部の長辺に沿った 2 列のみに 10 $\mathrm{cm}$ 間隔の合計 5 種類である. 鋼板とコンクリートの間 の自然付着を除去するために, 鋼板の上面に薄いビニー ルシートを敷き，その上にコンクリートを打設して，ス タッドのみで接合される合成床版とした．荷重の作用面 は $50 \mathrm{~cm} \times 20 \mathrm{~cm}$ で，図一10に示すように厚さ $30 \mathrm{~mm}$ の硬質ゴムパットを通して油圧ジャッキによって載荷し た。

スタッドは Nelson 型 $\phi 13 \times 80$ の頭付きで鋼板は SS-41 でスタッドの配列の一例を図一11(a) に示す. 表一6に供試体の種類とスタッド間隔を示すが，供試体 $\mathrm{E}-1, \mathrm{E}-2$ は長辺に最も近い端部の 2 列のみにスタッド を設けた。すべての実験床版は全周で単純支持で，四隅 の浮き上がりは防止した（図一10参照).コンクリート の力学特性を表一 6 に示す。また鋼板の降伏点は 2992 $\mathrm{kgf} / \mathrm{cm}^{2}$, 引張強度は $4107 \mathrm{kgf} / \mathrm{cm}^{2}$ であった。

次に，主な測定項目と測定方法を以下に示す.

(1) 長辺に平行な 1 つの支持線の半分に沿って反力計 （ロードセル）（図一10参照）を設置し，反力の分布を
調べる。

(2) スタッドに働くせん断力を求めるために, 着目ス タッドの中心から $15 \mathrm{~mm}$ 離れた両側に幅 $2 \mathrm{~mm}$ で長さ $50 \mathrm{~mm}$ のスリットを入れ，スリット間の 2 点の鋼板の 上下面にひずみゲージ（計 4 枚）を貼付し（図一11(b) 参照)，コンクリート打設前にスタッドの既知のせん断 力と鋼板の面内力差との関係を校正係数として求めてお き，コンクリート合成後のスタッドのせん断力を鋼板の ひずみゲージ值より算定する. 3. (2) での解析結果 (図 一4参照) が示すように，スリットは最大せん断力の方 向と平行であるので, スリットの導入はスタッドの最大 せん断力の値には大きな影響を与えないと考えた。

(3) 床版の中央点, それより $30 \mathrm{~cm}$ および $60 \mathrm{~cm}$ だ け長辺方向に離れた位置でのたわみを測定する。

(4) 床版の端部にП型ゲージを設定し, 鋼板とコンク リートの間のずれを測定する.

\section{(2) 実験結果と考察}

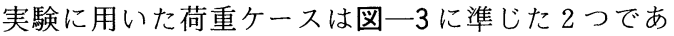
る. Case I は端部載荷で, 荷重面の縁が支持線に最も 近いスタッド列の直上にあり, 曲げモーメントの影響は 小さくせん断力が支配する場合で, Case II は中央点載 荷で，曲げモーメントの影響が大きい場合である．以下 に示す図, 表において座標 $(x, y)$ は図一3 を参照のこと.

a) 反力分布

端部載荷（Case I）に対して，長辺に沿った支持線 上の反力分布を図一12 に示す。図の中には比較のため に完全合成理論 ${ }^{4)}$ にる值も記入している. この理論值

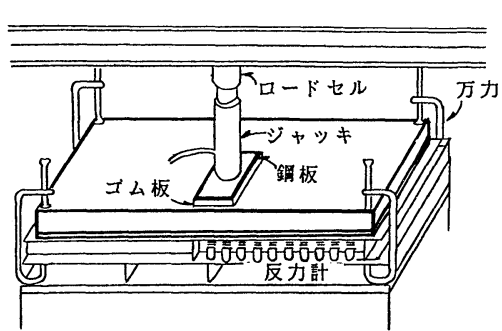

図一10 実験装置

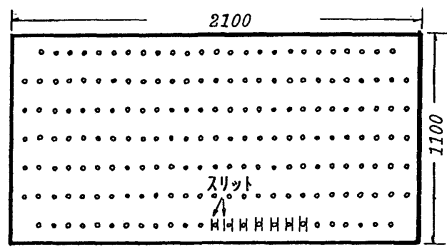

(a)鋼板

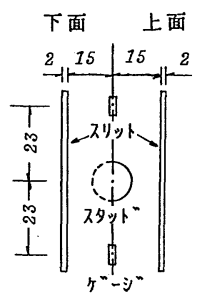

(b)ゲージ位置
図一11 スタッドの配置とせん断力の測定

表-6 供試体の種類とコンクリートのカ学特性

\begin{tabular}{|c|c|c|c|c|c|c|}
\hline \multirow{2}{*}{ 供試体 } & \multicolumn{2}{|c|}{ スタッド間隔 $(\mathrm{mm})$} & \multicolumn{4}{|c|}{ コンクリートのカ学特性 } \\
\hline & $\lambda x$ & $\lambda_{y}$ & $E_{c}$ & $f \circ c^{\prime}$ & $f t$, & 材令 (日) \\
\hline $\bar{A}$ & 75 & 150 & $1.84 \times 10^{5}$ & 329.4 & 27.5 & 44 \\
\hline$B-1$ & 100 & 150 & $1.89 \times 10^{5}$ & 264.8 & 24.1 & 30 \\
\hline$B-2$ & 100 & 150 & $1.92 \times 10^{5}$ & 305.7 & 28.2 & 37 \\
\hline$B-3$ & 100 & 150 & $1.92 \times 10^{5}$ & 308.6 & 28.5 & 65 \\
\hline$C-1$ & 150 & 150 & $1.89 \times 10^{5}$ & 264.8 & 24.1 & 30 \\
\hline$C-2$ & 150 & 150 & $1.92 \times 10^{5}$ & 308.6 & 28.5 & 65 \\
\hline D & 200 & 150 & $1.92 \times 10^{5}$ & 308.6 & 28.5 & 65 \\
\hline$E-1$ & 100 & - & $1.92 \times 10^{5}$ & 308.6 & 28.5 & 65 \\
\hline$E-2$ & 100 & - & $1.92 \times 10^{5}$ & 308.6 & 28.5 & 65 \\
\hline
\end{tabular}

(注) $\mathrm{E} \mathrm{c}$ :ヤング弯, $\mathrm{f}_{\mathrm{c}}{ }^{\prime}$ :压縮強度, $\mathrm{f} \mathrm{t}^{\prime}$ : 引張強度,

いずれも単位は $\mathrm{kgf} / \mathrm{cm}^{2}$ である。 
は鋼板とコンクリートが全面で完全に接合されていると して誘導されているが，実験值とほぼ一致している.

b）スタッドに働くせん断力

端部載荷（Case I ）で，長辺に沿った支持線に最も 近いスタッドの列の短スパン方向のせん断力の分布を図 -13に示す. 与えた荷重は $3 \mathrm{tf}$ 以内で, 版中央のたわ みと鋼板のひずみからみてほぼ線形弾性状態にあった。 図中, 破線は実験值で, 実線は本論文による理論值（た だし, $n=7, k_{x}=k_{y}=k_{z}=\infty$ ) および完全合成理論值 (積 層厚板理論(4)により求めた付着せん断応力をスタッド間 隔で積分した值）である. スタッド間隔が異なる供試体 $\mathrm{A}, \mathrm{B}, \mathrm{C}$ とも実験值は本論文による理論值によく一致 している.図より, スタッドに㗢く最大せん断力はスタッ ド間隔を変えてもさほど変化せず，これは完全合成理論 による結果と大きく異なっている. 次に, 最大せん断力 を与えるスタッドに着目し, さらに大きな荷重とせん断 力の関係を示したものが図一14である. 全体的には荷 重とせん断力の間にはほぼ線形関係が認められるが, 荷 重の増加につれてせん断力の増加率が若干大きくなる傾 向もみられる.この傾向は, 荷重の増加につれて, 鋼と コンクリートの見掛けの弾性係数比 $(n)$ が増加し, ス タッドに働くせん断力が大きくなることに対応してお り, 先に提案した式 $(15 \cdot b)$ の妥当性を裏付けている.

\section{c)たわみ}

床版がまだ線形弾性状態にあるときのたわみの測定值 を表一7に示す. 表には比較のため完全合成と非合成 (重 ね板）の理論值も示されている，ここで，たわみ值を用 いて合成率を次のように定義してみる.

$$
\eta=\frac{\delta_{0}-\delta_{e}}{\delta_{0}-\delta_{1}}
$$

ここに, $\delta_{e}$ : 実験值, $\delta_{1}$ : 完全合成理論值, $\delta_{0}$ : 非合成

(重ね板) 理論值である. 表一7を用いて式（18）の $\eta$

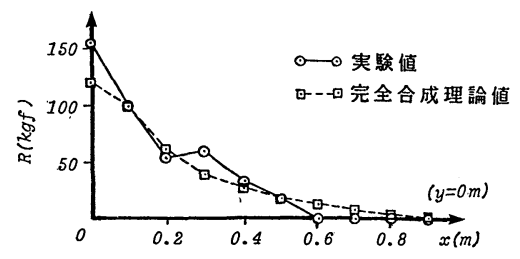

図一12 反力の分布 (供試体 A, Case I, $P=1 \mathrm{tf}$ )
を求めれば，表一8の結果を得る。これより，スタッド 間隔の最も小さい供試体 $\mathrm{A}$ はほぼ完全合成に近く，ス タッド間隔が大きくなるほど合成率の低下が認められ る.

d）スタッド近傍での鋼板のひずみ

鋼板の下面のスタッドの中心を通り長辺に平行な方向 に多くのひずみゲージを貼付し，鋼板の短スパン方向の
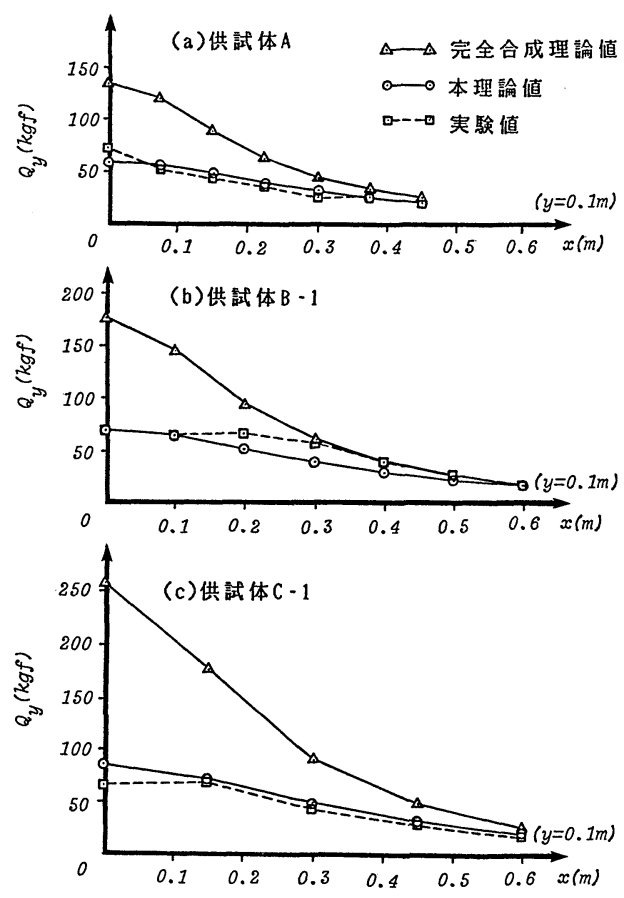

図一13 スタッドのせん断力分布 $(P=1 \mathrm{tf})$

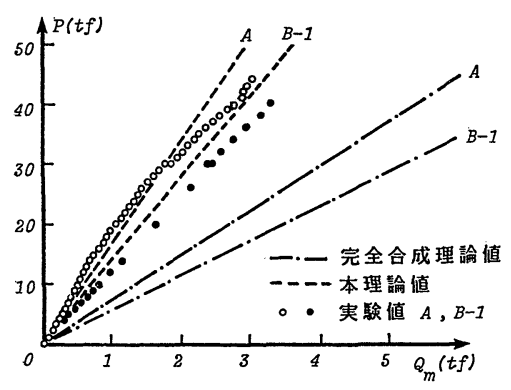

図一14 スタッドの最大せん断力の変化

表一7 たわみの測定值 $(\mathrm{mm} / \mathrm{tf})$

\begin{tabular}{c|ccc|ccc}
\hline \multirow{2}{*}{ 供試体 } & \multicolumn{2}{|c|}{ (a) 端部載荷:Case I } & \multicolumn{3}{c}{ (b)中央載荷:Case I } \\
\cline { 2 - 7 } & \multicolumn{2}{|c|}{ 测点 $(\mathrm{mm}), y=500$} & \multicolumn{3}{|c}{ 測点 $(\mathrm{mm}), y=500$} \\
\cline { 2 - 7 } & $x=0$ & 300 & 600 & $x=0$ & 300 & 600 \\
\hline 完全合成板* & 0.026 & 0.019 & 0.010 & 0.021 & 0.015 & 0.008 \\
A & 0.025 & 0.025 & 0.009 & 0.021 & 0.017 & 0.011 \\
B-1 & 0.029 & 0.029 & 0.016 & 0.028 & 0.021 & 0.013 \\
C-1 & 0.034 & 0.032 & 0.024 & 0.028 & 0.022 & 0.021 \\
非合成板** & 0.067 & 0.049 & 0.025 & 0.053 & 0.039 & 0.020 \\
\hline
\end{tabular}

表-8 合成率 $\eta$

\begin{tabular}{l|cc}
\hline 供試体 & $\begin{array}{c}\text { 端部载荷 } \\
\text { Case I }\end{array}$ & $\begin{array}{c}\text { 中央载荷 } \\
\text { Case I }\end{array}$ \\
\hline A & 1.00 & 1.00 \\
B - 1 & 0.93 & 0.78 \\
C - 1 & 0.80 & 0.78 \\
\hline
\end{tabular}


ひずみ分布を調べた，得られた結果と本理論による解析 值との比較を図一15に示すが，両者は定性的にはよく 一致していることがわかる、ひずみ分布が一様でなく波 打っているのはスタッド溶着部から鋼板に伝達される局 所曲げの影響およびスタッド間の鋼板のシャーラグ （shear lag）の影響によるものと思われる．本理論で はスタッド力は鋼板の上面に作用させており，鋼板厚の 1/2だけの腕のみによって局所曲げの効果を与えてい る.このようなひずみ分布の不均質性は完全合成理論で は説明できないものであるので，前述したようにたわみ 性からみればほぼ完全合成と思われる床版でも，スタッ ドに作用するせん断力は完全合成理論に従わない理由の $1 つ は$ 局所曲げやシャーラグの影響と推測される.

e) 破壊機構亡終局耐力

端部載荷および中央載荷時での破壊形状を図一16に 示す. 中央載荷の破壊形状は $\mathrm{RC}$ 床版の押し抜きせん 断形に類似し，端部載荷の破壊は支持線近傍の付着せん 断破壊に支配される。終局耐力（破壊荷重）を表一-9 の最後の列に示す．表中の計算值は RC 床版に対する 押し抜きせん断式を修正して以下のように求めた。

土木学会コンクリート・ライブラリーNo. 52 “コン クリート構造の限界状態設計法指針 (案)”9) で提案され た押し抜きせん断耐力の算定式は，

$$
P_{u}=f_{v d} u_{p} d / \gamma_{b}
$$

ここに, $f_{v d}=\beta_{r}\left(1+\beta_{d s}+\beta_{o}\right) f_{v 0 d}$,

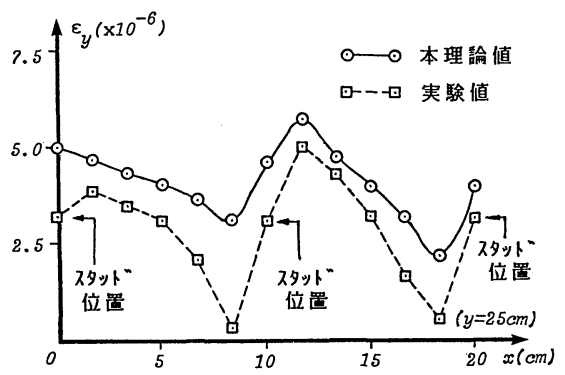

図一15 スタッド近傍の鋼板下面のひずみ分布

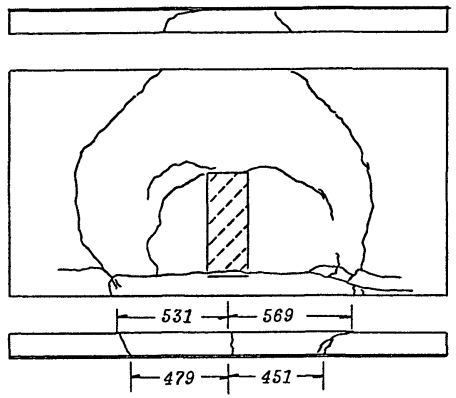

(a) Case $I(B-1)$

$$
\begin{aligned}
& \beta_{r}=2(0.85+0.4 d / r), \\
& \beta_{o}=\sqrt{\left(100 p_{w}\right)}-1 \leqq 0.73, \\
& \beta_{d s}=1.0-0.015 d \geqq 0.60(d: \mathrm{cm}), \\
& f_{v 0 d}=f_{v k} / \gamma_{c}\left(\mathrm{kgf} / \mathrm{cm}^{2}\right), \\
& f_{v k}=0.94 f_{c k}^{\prime 1 / 3}\left(\mathrm{kgf} / \mathrm{cm}^{2}\right), \\
& r=(u+v) / 2, d=h_{c}+t_{s} / 2, \\
& u_{p}=\left\{\begin{array}{cc}
0.5 \pi d+v+2(u+e): \text { for Case I } \\
\pi d+2(u+v) & \text { : for Case II }
\end{array}\right.
\end{aligned}
$$

$p_{w}$ は鉄筋比, $f_{c k}^{\prime}$ はコンクリートの圧縮強度で，他の 記号は図一17を参照のこと.なお，部分安全係数 $\gamma_{b}$ と $\gamma_{c}$ は実験值との対応を目的とし，いずれも 1 とした.

式 (19) において, 鉄筋の寄与は係数 $\beta_{\rho}$ のみに関し ているので，合成スラブに適用するために， $\beta_{\rho}$ を次の ように変更する.

$$
\beta_{\rho}=\sqrt{\left(100 \alpha p_{w}\right)}-1>0
$$

ここに, $p_{w}=t_{s} / d, t_{s}$ は鋼板厚, $\alpha$ は鋼断面の寄与率で, スタッドの強度と数によって決まる係数であり以下のよ うに評価する。

大野，水谷，小柳年にによれば， $\mathrm{RC}$ スラブの押し抜き せん断耐力は荷重面からほぼ $45^{\circ}$ の角度で広がるピラ ミッド形の破壊面の仮定によって算定できると述べてい る.本合成スラブにおいても同様の破壊面が仮定できる 亡し，押し抜きせん断破壊時には図一17に示す周長 $S$ で囲まれた面積 $A_{s}$ の内部の鋼板上のスタッドが付着せ ん断に抵抗すると考える.すなわち，面積 $A_{s}$ にスタッ ドが 1 本もなければ，コンクリート断面のせん断に対す

表一9＼cjkstart破壊荷重 $\left(\boldsymbol{P}_{u}\right)$ の実験値と計算值

\begin{tabular}{c|c|ccccc}
\hline $\begin{array}{c}\text { 載荷 } \\
\text { 位置 }\end{array}$ & 供試体 & $\begin{array}{l}\text { Qu } \\
\text { ( } \mathrm{tf})\end{array}$ & $\alpha$ & $\beta$ & \multicolumn{2}{c}{$\mathrm{P}$ ( $\mathrm{tf})$} \\
\hline \multirow{3}{*}{ 端部 } & $\mathrm{A}$ & 5.3 & 0.567 & 1.110 & 63.3 & 68 \\
Case I & $\mathrm{B}-1$ & 4.8 & 0.385 & 0.740 & 51.5 & 61 \\
& $\mathrm{C}-1$ & 4.8 & 0.257 & 0.421 & 45.1 & 52 \\
& $\mathrm{E}-1$ & 5.2 & 0.092 & 0 & 38.6 & 36 \\
\hline \multirow{5}{*}{ 中央 } & $\mathrm{B}-2$ & 5.2 & 0.446 & 0.873 & 67.5 & 64 \\
Case II & $\mathrm{B}-3$ & 5.2 & 0.446 & 0.873 & 67.5 & 63 \\
& $\mathrm{C}-2$ & 5.2 & 0.297 & 0.529 & 59.1 & 62 \\
& $\mathrm{E}-2$ & 5.2 & 0 & 0 & 45.8 & 41 \\
& $\mathrm{D}$ & 5.2 & 0.223 & 0.324 & 54.0 & 54 \\
\hline
\end{tabular}

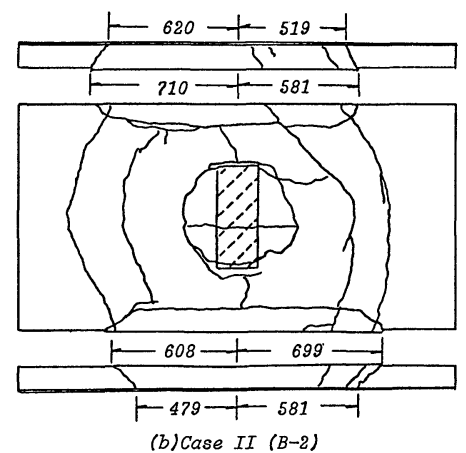

(b) Case II (B-2) 


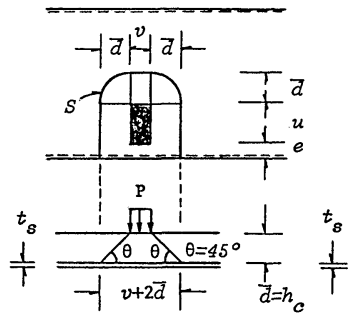

(a) Case I

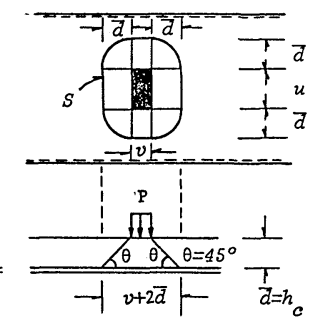

(b) Case II
図一17 仮定した押し抜きせん断破壊形式

る鋼板の拘束効果が期待できず，式（19）で鋼断面の寄 与 $p_{w}$ が零になると考える.

ところで，図一17において付着せん断破壊を伴わな いで押し抜きせん断破壊を起こすためには，最大曲げ モーメントの位置での鋼板の応力が降伏応力に達するま で, 面積 $A_{s}$ 内のスタッドが付着せん断力に抵抗する必 要がある.この抵抗力を $R_{u}$ とし，1 方向スラブに対し ては，次式で与えられるとする.

$$
R_{u}=t_{s}(v+2 \bar{d}) \sigma_{s y}
$$

ここに, $\sigma_{s y}$ は鋼板の降伏応力, $\bar{d}\left(=h_{c}\right)$ はコンクリー

卜部の厚み. したがって，スタッド 1 本のせん断耐力 $Q_{u}$ を Fisher ら ${ }^{7)}$ 提案式より求める.

$$
Q_{u}=0.5 a_{s} \sqrt{\left(f_{c}^{\prime} E_{c}\right)}
$$

ここに， $a_{s}$ はスタッドの断面積， $E_{c}$ はコンクリートの ヤング率.いま，スタッド間隔が $\left(\lambda_{x} \times \lambda_{y}\right)$ とすれば, 式 (20) の中の $\alpha$ は次のように与えられる.

$$
\alpha=\frac{Q_{u} A_{u}}{2 R_{u} \lambda_{x} \lambda_{y}} \leqq 1
$$

最後に, $f_{c}^{\prime}=f_{c d}^{\prime}=f_{c k}^{\prime}, d=11.45 \mathrm{~cm}, u=50 \mathrm{~cm}, v$ $=20 \mathrm{~cm}$ とし，表一 6 の材料定数と各供試体の諸元を用 いて式 (21) の $\alpha$ 亡式 (20)の $\beta_{o}$ を求め, さらに式 (19) の $P_{u}$ を計算すれば，表一9の結果を得る.

\section{5. 結 論}

本研究で得られた主な事項を以下にまとめる.

（1）弾性域内でのスタッドに㗢く最大せん断力に対 して, 本論文で展開した厚板理論に基づく選点法による 解析値は実験值によく一致していた。

（2）床版の中央点載荷より支持辺近傍の端部載荷の 方がスタッドに作用する最大せん断力の值は大きい.

（３） スタッドの最大せん断力の值はスタッド間隔が 大きくなるにつれて大きくなるが，増加率は小さく，完 全合成理論加得られる傾向と大きく異なっている.

（4）たわみ性（剛性）からみてほとんど完全合成と 思われる密なスタッド間隔の場合でも，スタッドに働く せん断力は完全合成理論で求めた值よりかなり小さい.
（5） スタッドの変形，すなわち鋼板とコンクリート との間のずれはスタッドの最大せん断力の值を低減させ るが，スタッドのずれ係数が $50 \times 10^{4} \mathrm{kgf} / \mathrm{cm}$ 以上にな れば，その影響がほとんどなくなる。

（6）完全合成理論に従わない理由の 1 つにスタッド 溶植部の鋼板の局所曲げと鋼板の面内力に関するシャ一 ラグの影響が考えられた。

（７）完全合成理論に基づくせん断有効幅 ${ }^{4} や \mathrm{ECCS}$ の提案式8)用いて，スタッドのせん断力を計算すれば 実際に働くせん断力よりも過大な值を与える。

（８）実用的と思われる範囲内の諸元をもつ鋼板・コ ンクリート合成床版のスタッドに㗢く最大せん断力の值 は式 (17)によって工学的には十分な精度で予測できる.

（9）鋼板・コンクリート合成床版の終局せん断耐力 は RC 床版の押し抜きせん断耐力に対する既往の提案 式を若干修正することによっておおむね予測できる.

\section{参 考 文 献}

1) Johnson, R.P. and Buckby, R. J. : Composite Structure of Steel and Concrete, Vol.2, Bridge with a Commentary on BS5400 Part 5, Gradana Publishing, 1975.

2）新津啓治・浅島弘光・大貫一生・落合正利：鋼製型枠合 成床版を用いた合成桁の設計・施工, 橋梁と基礎, Vol. 14, No. 11, pp. 42 49, 1980.

3）梶川靖治・前田幸雄：組合せ荷重下におけるスタッド溶 接フランジの疲労強度の評価, 土木学会論文集, No. 362, pp. 285 292, 1985 .

4）園田恵一郎・堀川都志雄 - 広瀬清泰 : 道路橋鋼板・コン クリート合成床版のずれ止めの設計に関するせん断有効 幅，土木学会論文報告集，No. 338, pp. 1 9, 1983.

5）堀川都志雄・園田恵一郎：道路橋鋼板・コンクリート合 成床版のスタッドに働くせん断力の解析と実験, 構造工 学論文集, Vol.33A, pp. 299 306, 1987.

6）園田恵一郎・堀川都志雄：道路橋床版の輪荷重直下の応 力の算定について, 土木学会論文報告集, No. 273, pp. 15 22, 1978 .

7) Ollgaard, J.G., Slutter, R.G. and Fisher, J.W. : Shear strength of stud connectors in light-weight and normal-weight concrete, AISC Eng. Jour., No. 5, pp. 55 $\sim 64,1971$.

8) European Convention for Construction Steelwork, Composite Structures, The Construction Press, London, 1981.

9）土木学会コンクリート委員会 : コンクリート構造の限界 状態設計法指針(案), コンクリートライブラリー, No. 52, 1983.

10）大野定俊・水谷 隆・小柳 洽 : RC スラブの押し抜き せん断破壊のモデル化と終局耐力, $\mathrm{RC}$ 構造のせん断問 題に対する解析的研究に関するコロキュウム論文集, pp. $69 \sim 76,1982$.

(1988.2.19・受付) 